\title{
FREQUENCY OF SOIL CONTAMINATION BY ToXocara canis EGGS IN THE SOUTH REGION OF SÃO PAULO MUNICIPALITY (SP, BRAZIL) IN A 18-MONTH PERIOD
}

\author{
Maisa Leite de QUEIRoZ(1), Marcelo SIMOnSEn(2), Maria Aparecida PASCHOAlotTi(2) \& Pedro Paulo CHIEFFI(1, 2)
}

\section{SUMMARY}

Soil contamination by embryonic eggs of Toxocara canis is the main source of human infection by this ascarid larvae resulting, sometimes, in the occurrence of visceral larva migrans syndrome. The objective of the present research is to determine the frequency of T. canis eggs in soil samples monthly collected in nine public places, located at the South Region of São Paulo municipality in a 18-month period, from February 2004 to July 2005. The soil samples collected were treated with a 30\% antiformine solution and with a sodium dichromate solution $(\mathrm{d}=1.40)$ and microscopic slides were prepared and examined under light microscopy for searching T. canis eggs. Two peaks of higher frequency had been found, one in February - May 2004 and the other in April - July 2005.

KEYWORDS: Toxocara canis; Soil contamination; São Paulo.

\section{INTRODUCTION}

Human infection by Toxocara canis larvae has been frequently described as a common event and of cosmopolitan distribution ${ }^{3,14,18}$. It usually presents an asymptomatic course, but it is known as visceral larva migrans syndrome or human toxocariasis when inducing some human complaints ${ }^{14,18}$.

Several surveys carried out in Brazil showed changeable frequencies of human infection by $T$. canis $^{1,2,9,10}$ and commonly soil contamination by this ascarid eggs has been reported $d^{2,5,7,8,9,11,12,13}$. However, studies regarding seasonal variations in soil contamination of public places by Toxocara eggs are very scarce s,11,17,19. $^{6}$

In this paper, the soil contamination by $T$. canis eggs in nine public places located in the South Region of São Paulo municipality was monthly investigated during a period of 18 months, in order to determine the possible existence of seasonal variations.

\section{MATERIAL AND METHODS}

Monthly, from February 2004 to July 2005, samples of $500 \mathrm{~g}$ of soil were collected in six different points of nine public places (six squares and three glebes) located in the South Region of São Paulo municipality. All places were chosen according to some criteria: localization, soil pattern and presence of dogs and/or children nearby.

After collection, the soil samples were immediately transported to the Parasitology Laboratory at Santa Casa Medical School where, after careful homogenization, were separated into aliquots of $20 \mathrm{~g}$ and submitted to treatment with a modified antiformine solution and analyzed with sodium dichromate solution in conic glasses used for fecal sedimentation for $T$. canis eggs searching. After 15 minutes six drops of the superficial layer from each glass were obtained in order to prepare three microscopic slides of each soil sample and, subsequently, to examine the slides under light microscopy.

T. canis eggs were classified according to their morphological aspects in viable and non-viable in all the examined samples.

\section{RESULTS}

Figure 1 shows the total number of $T$. canis eggs recovered from soil samples each month from February 2004 to July 2005, in all nine places where this study was carried out. It was possible to notice two peaks of $T$. canis eggs recovered, one in 2004 from February to May and the other in 2005 from April to July.

\section{DISCUSSION}

The importance of soil contaminated by $T$. canis eggs as a vehicle capable of transmitting human toxocariasis in public places has been worldwide demonstrated ${ }^{14,18}$. However, the recovery of Toxocara eggs in soil samples should be influenced by several physical, environmental and methodological factors, rendering difficult the evaluation of seasonal variations in soil contamination by those ascarid eggs,

(1) Instituto de Medicina Tropical de São Paulo (LIM-06), São Paulo, SP, Brasil.

(2) Faculdade de Ciências Médicas da Santa Casa de São Paulo, São Paulo, SP, Brasil.

Correspondence to: Prof. Dr. Pedro Paulo Chieffi, Av. Dr. Enéas C. Aguiar 470, 05403-000 S. Paulo, SP, Brasil. E-mail: pchieffi@usp.br 


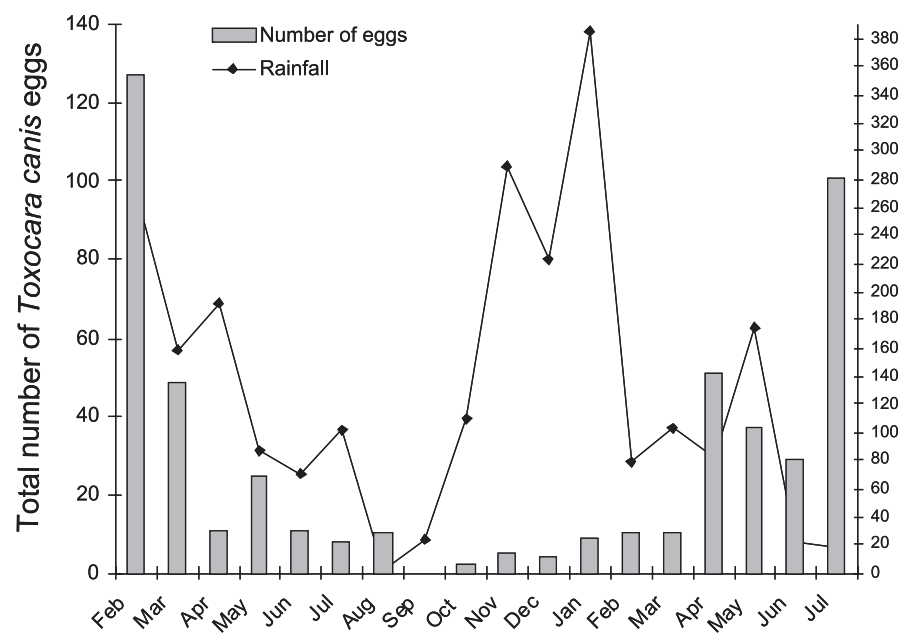

February 2004 to May 2005

Fig. 1 - Total number of Toxocara canis eggs recovered from soil samples collected of nine areas in the period between February/2004 and July/2005 and monthly rain precipitation.

justifying the scarcity of this kind of research ${ }^{15,16}$. There are, nevertheless, some evidence suggesting higher frequencies of soil contamination by Toxocara eggs in certain year periods, resulting in higher risk for toxocaral human infection.

CHIEFFI \& MÜLLER ${ }^{8}$ showed, for the first time in Londrina (Paraná State), seasonal variations in the presence of T. canis eggs in soil samples monthly collected during one year. CASEIRO ${ }^{6}$, analyzing the presence of $T$. canis eggs in the soil of some localities of Santos, municipality located in the coastal region of São Paulo State, found similar results. SALINAS et al. ${ }^{17}$ also showed a seasonal trend in the contamination by T. canis eggs in soil samples collected in public squares of Santiago (Chile), but the period of higher frequency of egg recovered was during the autumn and the winter. SHIMIZU ${ }^{19}$ recorded the presence of $T$. canis eggs in sandpits, where children usually played, in public parks of Tokushima (Japan), showing a higher frequency of egg recovering during the autumn, spring and the beginning of summer. However, SHIMIZU ${ }^{19}$, as well as, CHIEFFI \& MÜLLER ${ }^{8}$ pointed towards the possibility of the higher presence of puppies in the periods of best recovering of $T$. canis eggs in the soil as a consequence of a higher rate of occurrence of rut in female dogs two months before.

In the present paper it was observed the occurrence of two peaks of higher frequency of $T$. canis eggs recovered in the soil samples examined in the periods from February - May 2004 and April - July 2005 , but the variations were not so clear as those found by others ${ }^{6,11,17,19}$. Albeit the finding of higher frequency of Toxocara eggs in soil samples collected between April and July 2005, period in which a great number of puppies should be expected, it did not become so clear a correlation between the occurrence of rut in female dogs some months before and the enhancement of the eggs recovered, resulting impossible the complete confirmation of the hypothesis suggested by CHIEFFI \& MÜLLER $^{8}$ and partially supported by SHIMIZU ${ }^{19}$ and CASEIRO $^{6}$.

It should be possible that the pattern of raininess verified during the period in which this study was carried out has had some influence in the finding of Toxocara eggs in soil samples, once rain is known as an important factor for nematode eggs dispersion ${ }^{4}$. So, the higher rates of rain precipitation occurred in 2004 should hamper one seasonality episode.

\section{RESUMO}

Freqüência de contaminação do solo por ovos de Toxocara canis em amostras coletadas na região sul do município de São Paulo (SP, Brasil) durante o período de 18 meses

A contaminação do solo por ovos larvados de Toxocara canis é a principal fonte de infecção de seres humanos por larvas desse ascarídeo que, com freqüência, determinam ocorrência da síndrome de larva migrans visceral. No presente trabalho procurou-se investigar a frequiência com que são recuperados ovos de T. canis em amostras de solo, coletadas mensalmente, em nove localidades públicas, situadas na região sul do município de São Paulo, durante o período compreendido por fevereiro de 2004 e julho de 2005.

As amostras coletadas foram inicialmente tratadas com solução de antiformina a $30 \%$, e, a seguir, com solução saturada de dicromato de sódio $(\mathrm{d}=1,40)$, preparando-se lâminas com alíquotas da camada superficial da solução final onde se pesquisou, com auxílio de microscópio óptico, a presença de ovos de T. canis. Observou-se a ocorrência de duas ocasiões em que foi maior a freqüência de ovos nas amostras analisadas: uma no período compreendido entre fevereiro e maio de 2004 e outra entre os meses de abril e julho de 2005.

\section{ACKNOWLEDGEMENTS}

Authors are grateful to the metereologic station of the Instituto de Astronomia, Geofísica e Ciências Atmosféricas for the supply of pluvial precipitation rates in the South Region of São Paulo, during the period 2004-2005.

\section{REFERENCES}

1. ALDERETE, J.M.S.; JACOB, C.M.A.; PASTORINO, A.C. et al. - Prevalence of Toxocara infection in schoolchildren from the Butantã Region, São Paulo, Brazil. Mem. Inst. Oswaldo Cruz, 98: 593-597, 2003.

2. ANARUMA FILHO, F. - Toxocaríase humana e parasitoses intestinais em áreas sob o risco de enchentes no município de Campinas, Estado de São Paulo, Brasil. Campinas, 2002. (Tese de Doutorado - Universidade Estadual de Campinas).

3. BARRIGA, O.O. - A critical look at the importance, prevalence and control of toxocariasis and the possibilities of immunological control. Rev. Parasit., 29: 195-234, 1988.

4. BEAVER, P.C. - Biology of soil-transmitted helminths: the massive infection. Health Lab. Sci., 12: 116 -125, 1975.

5. CAMPOS, D.M.B.; LEÃO, D.A.; ISAC, E. \& CALIL, F. - Pesquisa de ovos de Toxocara sp. em localidades públicas da cidade de Goiânia, Goiás. 1. Comparação de métodos de exame. Rev. Pat. trop., 16: 7-11, 1987.

6. CASEIRO, M.M. - Síndrome de Larva Migrans Visceral causada por larvas de Toxocara canis (Werner, 1782 e Stiles, 1905), no município de Santos, São Paulo, 1994-1996. São Paulo, 1996. (Dissertação de Mestrado - Faculdade de Medicina da Universidade de São Paulo). 
QUEIROZ, M.L.; SIMONSEN, M.; PASCHOALOTTI, M.A. \& CHIEFFI, P.P. - Frequency of soil contamination by Toxocara canis eggs in the South Region of São Paulo municipality (SP, Brazil) in a 18-month period. Rev. Inst. Med. trop. S. Paulo, 48(6): 317-319, 2006.

7. CHIEFFI, P.P. \& MÜLLER, E.E. - Prevalência de parasitismo por Toxocara canis em cães e presença de ovos de Toxocara sp. no solo de localidades públicas da zona urbana do município de Londrina, Estado do Paraná, Brasil. Rev. Saúde públ. (S. Paulo), 10: 367-372, 1976.

8. CHIEFFI, P.P. \& MÜLLER, E.E. - Estudo da variação mensal na contaminação do solo por ovos de Toxocara sp. (Nematoda, Ascaroidea), na zona urbana do Município de Londrina, Estado do Paraná, Brasil. Rev. Inst. Adolfo Lutz, 38: 13-16, 1978.

9. COELHO, L.M.P.S.; DINI, C.Y.; MILMAN, M.H.S.A. \& OLIVEIRA, S.M. - Toxocara spp. eggs in public squares of Sorocaba, São Paulo State, Brazil. Rev. Inst. Med. trop. S. Paulo, 43: 189-191, 2001.

10. COÊLHO, R.A.L.; CARVAlHO JÚNIOR, L.B.; PEREZ, E.P. et al. - Prevalence of toxocariasis in Northeastern Brazil based on serology using recombinant Toxocara canis antigen. Amer. J. trop. Med. Hyg., 72: 103-107, 2005.

11. COSTA-CRUZ, J.M.; NUNES, R.S. \& BUSO, A.G. - Presença de ovos de Toxocara spp. em praças públicas da cidade de Uberlândia, Minas Gerais, Brazil. Rev. Inst. Med. trop. S. Paulo, 36: 39-42, 1994.

12. FERREIRA, L.F.; OLIVEIRA, E.L. \& CAMILLO-COURA, L. - Sobre a presença de ovos de Toxocara, em praças da cidade do Rio de Janeiro. Rev. Soc. bras. Med. trop., 10: 51-54, 1976.
13. GUIMARÃES, A.M.; ALVES, E.G.L.; REZENDE, G.F. \& RODRIGUES, M.C. - Ovos de Toxocara sp. e larvas de Ancylostoma sp. em praça pública de Lavras, MG. Rev. Saúde públ. (S. Paulo), 39: 293-295, 2005.

14. OVERGAAUW, P.A.M. - Aspects of Toxocara epidemiology: human toxocarosis. Crit. Rev. Microbiol., 23: 215-231, 1997.

15. PÉREZ, R.M.L.; ARRIETA, D.C.; ZAMORA, E.M.R.; ROCHE R.G. \& DIAZ, V.P. Toxocara sp. en parques y zonas públicas de ciudad de la Habana. 1995. Rev. cubana Hig. Epidem., 38: 112-116, 2000.

16. REGO, A. - Contaminação do solo de parques e praças de Lisboa por ovos de Toxocara e outros helmintos. An. Esc. sup. Med. vet., 22: 51-62, 1980

17. SALINAS, P.; REYES, L.; SOTOMAYOR, M.T. \& LETONIA, T. - Prevalencia de huevos de Toxocara sp. em algunas plazas públicas de la región Metropolitana de Santiago, Chile. Bol. chil. Parasit., 42: 33-36, 1987.

18. SCHANTZ, P.M. - Toxocara Larva Migrans now. Amer. J. trop. Med. Hyg., 41(supl. 3): 21-34, 1989.

19. SHIMIZU, T. - Prevalence of Toxocara eggs in sandpits in Tokushima City and its outskirts. J. vet. Med. Sci., 55: 807-811, 1993.

Received: 19 June 2006

Accepted: 30 August 2006 